\title{
Psychosocial triggers associated with major depressive episodes in women applying to psychiatric outpatient clinic
}

\section{Psikiyatri polikliniğine başvuran major depresyon tanılı kadın hastalardaki potansiyel tetikleyiciler olarak psikososyal stresörler}

\author{
Tonguç Demir Berkol ${ }^{1}$ (D), Hasan Mervan Aytaç ${ }^{2 *}$ \\ 1 Department of Psychiatry, Bakırkoy Research and Training Hospital for Psychiatry, Neurology and Neurosurgery, Istanbul, Turkey \\ ${ }^{2}$ Malazgirt State Hospital, Mus, Turkey \\ * Corresponding author: Hasan Mervan Aytaç E-mail: mervan176@hotmail.com ORCID: 0000-0002-1053-6808 \\ Received: 28 November 2019 Accepted: 27 February 2020
}

\begin{abstract}
Aim: Factors such as personality traits, self-esteem, interpersonal relations and cognitive skills are considered among the risk factors of psychiatric disorders particularly for mood disorders. Presence of a single risk factor is not enough for the disease to emerge. The present study aimed to evaluate the presence of psychosocial triggering factors prior to the episodes of major depressive disorder (MDD) in female patients.

Materials and Methods: This retrospective study included a total of 62 female patients, who visited the psychiatry policlinic and have been diagnosed with MDD alone according to SCID-I. After the diagnostic evaluation of the patients, detailed clinical interview was conducted to assess the presence of triggering factors for depressive episode. All of the participants described triggering factors for major depressive disorder.

Results: Regarding the psychosocial factors as the potential triggers, 26 patients mentioned about the problem of communication and compliance with the spouse (42\%), 10 mentioned about the presence of illness in the first-degree relatives $(16 \%)$ and 10 mentioned about the conflict with the mother-in-law or other relatives (16\%). When we collect "communication/compliance problem with the spouse" + "conflict with the mother-in-law/other family members" + "breaking up with the beloved one" + "husband's cheating on her" stressor groups as a "relationship conflict" group, the mean of BDI and BAI scores of "relationship conflict" group were highest among the all groups.
\end{abstract}

Conclusions: In the light of these outcomes, it can be concluded that particularly psychosocial factors associated with interpersonal relations play significant role as the triggering factors for depressive episodes in female patients. Among these factors, the problem of communication and compliance with the spouse is particularly striking.

Keywords: depression, female, psychosocial trigger

( 2020 by the authors; licensee MEDITAGEM Ltd., Turkey. This article is an open access article distributed under the terms and conditions of the Creative Commons Attribution License (http://creativecommons.org/licenses/by/4.0/). 


\section{öz}

Amaç: Kişilik özellikleri, öz-saygı, kişilerarası ilişkiler ve bilişsel beceriler gibi faktörler, özellikle duygudurum bozuklukları başta olmak üzere psikiyatrik bozuklukların risk faktörleri arasında sayılmaktadır. Hastalığın ortaya çıkması için tek bir risk faktörünün varlığı yeterli değildir. Genetik yapının olumsuz çevresel faktörlerle etkileşimi de önemlidir. Bu çalışmada, kadın hastalarda major depresyon epizodlarından önce psikososyal tetikleyici faktörlerin varlığını değerlendirmeyi amaçladık.

Gereç ve Yöntemler: Psikiyatri polikliniğine başvuran ve SCID-1 ile major depresyon tanısı konulan toplam 62 kadın hasta retrospektif şekilde dizayn edilmiş olan çalışmaya alındı. Hastaların tanısal değerlendirmesinden sonra, depresif atak için tetikleyici faktörlerin varlığını değerlendirmek amacıyla ayrıntılı klinik görüşme yapıldı.

Bulgular: Potansiyel tetikleyiciler olarak psikososyal faktörlerle ilgili olarak, hastaların 26'sı eşi ile ilgili iletişim ve uyum hakkında (\%42), 10'u birinci derece akrabalarda hastalık varlığından (\%16), 10'u da kayınvalidesi ve veya başka akrabalarıyla olan anlaşmazlıktan bahsetmiş olup 8'i taşınmadan (\%13), 6'sı sevgiliden ayrılmadan (\%10) ve 2'si de eş aldatmasından bahsetmiştir (\%3). "Eş ile iletişim / uyum sorunu", "kayınvalidesiyle / diğer aile üyeleriyle anlaşmazlık", "sevgilisinden ayrılmak" ve "eşi tarafından aldatılmak" stresörleri "ilişki çatışması" grubunda toplandığında bu grubun depresyon ve anksiyete skorlarının ortalaması tüm gruplar arasında en yüksek oranda bulunmuştur.

Sonuç: Bu bulgular ışığında, özellikle kadınlarda depresyon atakları için tetikleyici faktörler olarak kişilerarası ilişkilerle ilişkili psikososyal faktörlerin önemli rol oynadığı sonucuna varılabilir. Bu faktörler arasında eş ile iletişim ve uyum sorunu özellikle dikkat çekicidir.

Anahtar kelimeler: depresyon, kadın, psikososyal tetikleyici

\section{INTRODUCTION}

The relationship between major depressive disorder (MDD) and previous unfavorable psychosocial life events has been unveiled by many researchers [1-3]. Although a single factor is not enough for the disease to emerge, the interaction between genetic structure and unfavorable environmental factors exceeding a certain threshold and its timing are important. Approximately $70 \%$ of first depression attacks and $40 \%$ of recurrent episodes are triggered by a severe stressful life event [4]. In the literature, female gender, age over 40 years, unemployment, being single or divorced, genetic susceptibility, depressive personal trait, low education, unfavorable life events such as immigration etc., lack of close relationship, physical illness and treatment, and psychiatric disorders causing loss of skill have been propounded as the main risk factors for major depression. The intensity of the effect of these risk factors changes due to the type of depression. For example, while biological susceptibility plays more important role in those with severe depression, the role of environmental factors gains importance in those with mild depression [5]. It has been argued that severe life events are the most important trigger factor for depression. The studies which were conducted with population-based sample size, state that stress is reported 2.5 times more by MDD patients than the controls and that $80 \%$ of the patients have experienced serious stressful life events before the emergence of MDD [2]. Quality of social relationships, which is one of the psychosocial factors, is a major risk factor for major depression [6]. The relationship between depression and migration, which is another important factor for our country in recent times, has also been demonstrated in a metaanalysis study [7]. It is reported that loss and separation are the leading life events that precede MDD [8]. Moreover, it is thought that loss and separation might be associated rather with MDD than the other psychopathologies. There are a lot of points that may affect patients' susceptibility to depression in the face of stress. There is evidence that the patients with a history of depression are more vulnerable to episodesof depression in response to stressful life events. The patients with a history of depression are more likely to become depressed following a nonsevere event [9]. In addition, for those with several past episodes of depression, chronic stress appears to play a key role in triggering recurrences of depression [10]. The present study aimed to determine the psychosocial stress factors that may be the potential triggers in female MDD patients visiting the policlinic of a training and research hospital. The hypothesis of our study was that psychosocial factors associated with interpersonal relations play significant role as the triggering factors for depressive episodes in female patients. 


\section{MATERIALS AND METHODS}

A total of 62 female patients, who consecutively visited Bakırköy Prof. Dr. Mazhar Osman Mental Health and Neurological Diseases Education and Research Hospital, psychiatry policlinic between January and March 2017, who have been diagnosed with MDD based on the DSM-IV criteria, who were older than 18-year-old, and who have visited the psychiatry policlinic and been diagnosed with major depression for the first time, were enrolled into the study. The study was designed retrospectively. However, the treatment records were obtained from a depression followup program, which also covered their treatment schedule. Since the study was designed retrospectively, scientific suitability approval was obtained from the education supervisor of the No.1 psychiatry outpatient clinic of Bakırköy Prof. Dr. Mazhar Osman Mental Health and Neurological Diseases Education and Research Hospital, where the patients were collected for the study. The patients had no co-morbidity other than major depression according to SCID-I criteria. The female patients, who have been diagnosed with first episode of major depressive disorder, completed the Structured Clinical Interview for DSM IV AxisI Disorders (SCID-I), which was customized for the study, as well as socio-demographic data form, Beck Depression Inventory and Beck Anxiety Inventory, Clinic Global Impression Scale and Global Assessment Scale.

\section{Study Inclusion Criteria}

Being older than 18 years, volunteer to participate in the study, not having mental retardation, not having comorbidity other than major depression according to SCID$\mathrm{I}$, and the major depression's not being psychotic.

\section{Study Exclusion Criteria}

The patient with mental retardation, psychiatric disorder due to general medical condition and alcohol or substance abuse again the patient whose language and education level not sufficient to perform psychiatric interview were not included in the study.

A specialist clinician interviewed the patients and applied the scales to make the diagnosis and to determine the psychosocial stress factors. Within the interviewing period, the patients were questioned about the factors that were probably associated with the emergence of the symptoms of MDD and, if any, detailed anamnesis was taken. Psychosocial factors were classified under general topics including familial relations, health status of the subject or the relatives, economic problems, and moving/immigrating.

\section{Sociodemografic Data Form}

A data form that includes questions about clinical features, basic symptoms of the disease, past and current conditions of the patients' illnesses, and treatments applied during the past and hospitalization.

\section{Structured Clinical Interview for DSM IV Axis I Disorders (SCID-I)}

SCID-I is a structured clinical interview developed to make the diagnosis of psychiatric disorders in accordance with DSM IV Diagnostic Classification [11]. It is established for the use of specialists experienced in the field of psychiatry. During the interview, the interviewer can benefit from the other sources of knowledge in addition to the patient's answers. The validity and reliability study for Turkish population was done by Çorapçığlu and the colleagues [12].

\section{Clinical Global Impression Scale}

It is a scale evaluating in general the severity of any disease or the improvement of disease symptoms. The clinician rates the severity or improvement of the disease between 0 (not ill) and 7 (very severe) depending on his/her own overall experience concerning the disease in question [13].

\section{Beck Depression Inventory (BDI) and Beck Anxiety Inventory (BAI)}

$\mathrm{BDI}$ is a 21 -item scale evaluating the signs and symptoms of depression and scored as the sum of the answers. Each item is rated between 0 and 3; higher scores indicate severer disease. Total score is the sum of the scores and interpreted as following: 0 - 10: no depression, 11 - 17: mild depression, 18 - 23: moderate depression, $\geq 24$ : severe depression [14, 15]. BAl is a 21-item self-report scale, which is defined as the generalized symptoms of anxiety the subject experienced in the last week. The highest score of BAl is 63 ( 0 - 7: minimal anxiety, 8 - 15: mild anxiety, 16 - 25: moderate anxiety, 26 63: severe anxiety) $[16,17]$.

\section{Global Assessment Scale}

The patient's lowest level of social, occupational and mental functionality is determined based on the patient's status in the last week. It is rated from 1 (lowest) to 100 (highest) with 0 representing inadequate information [18].

\section{Statistical Analysis}

The data were analyzed using the Statistical Program for Social Sciences (SPSS) version 16.0 (SPSS Inc., Chicago, IL, USA). Normality of continuous data was determined by Shapiro-Wilk normality test. For continuous data with 
Table 1. Sociodemographic characteristics of the patients diagnosed with major depression

\begin{tabular}{|c|c|c|}
\hline \multicolumn{1}{|c|}{} & $\mathbf{N = 6 2}$ & $\%$ \\
\hline Marital Status & 48 & 77.4 \\
Married & 12 & 19.4 \\
Single & 2 & 3.2 \\
\hline Divorced & & \\
\hline Child $\quad$ Yes & 50 & 80.6 \\
No & 12 & 19.4 \\
\hline Living with & 52 & \\
Elementary family & 10 & 16.1 \\
Mother-in-law & & \\
Marriage & 32 & 52.0 \\
Flirting & 30 & 48.0 \\
Arranged & & \\
Voluntary & 44 & 72.0 \\
Involuntary & 18 & 28.0 \\
\hline Desire for marriage & & \\
Yes & 12 & 20.0 \\
No & 50 & 80.0 \\
\hline
\end{tabular}

Table 2. Clinical features and scale scores of the patients diagnosed with major depression

\begin{tabular}{|l|c|c|}
\hline & Mean & Standard deviation \\
\hline Age, year & 29.0 & 7.9 \\
\hline Duration of education (year) & 8.1 & 3.2 \\
\hline Duration of marriage (year) & 10.8 & 6.7 \\
\hline Clinical Global Impression (CGI) & 4.3 & 0.7 \\
\hline Global Assessment Scale (GAS) & 55 & 7.1 \\
\hline Beck Depression Inventory (BDI) & 31.7 & 8.8 \\
\hline Beck Anxiety Inventory (BAI) & 38.5 & 13.6 \\
\hline
\end{tabular}

normal distribution, one-way analysis of variance (ANOVA) was used to compare means of more than two groups. Tukey's HSD test was applied as post-hoc, when one-way ANOVA test showed a significant difference between the groups. A $p$ value of $<0.05$ was considered statistically significant.

\section{RESULTS}

The study population consisted of 48 married, 12 single and 2 divorced females, of whom 50 had children and 12 had none; 10 have been living with the mother-in-law, whereas the others have been living as elementary (nuclear) family; 32 married after flirting and 30 had their marriage arranged; 44 married voluntarily, whereas the others married involuntarily. Domestic violence was in question in 12 patients (Table 1).

In the married group, 10 have been living with the husband's family. The mean patient age was $29 \pm 7.9$ years, the mean duration of education was $8.1 \pm 3.2$ years, and the mean duration of marriage was $10.8 \pm 6.7$ years. The patients' mean BDI score was $31.7 \pm 8.8$ and the mean BAl score was
Table 3. Psychosocial stressors as the potential trigger of major depression

\begin{tabular}{|l|c|c|}
\hline & $N$ & $\%$ \\
\hline Communication/compliance problem with the spouse & 26 & 42 \\
\hline Conflict with the mother-in-law/other family members & 10 & 16 \\
\hline Health problem/illness of the relatives & 10 & 16 \\
\hline Moving & 8 & 13 \\
\hline Breaking up with the beloved one & 6 & 10 \\
\hline Husband's cheating on her & 2 & 3 \\
\hline
\end{tabular}

$38.5 \pm$ 13.6. The mean scores of clinical Global Impression Scale and Global assessment Scale were $4.3 \pm 0.7$ and $55 \pm$ 7.1, respectively (Table 2 ).

All of the patients mentioned about triggering factors for depressive disorder. Of these patients, 26 pointed out the problem of communication and compliance with the husband (42\%); 10 pointed out the presence of illness in the first-degree relatives (16\%); 10 pointed out conflicts with mother-in-law or other family members (16\%); 8 pointed out moving (13\%); 6 pointed out break up with the beloved one (10\%) and 2 pointed out their husbands' cheating on them (3\%) as the potential psychosocial triggering factor (Table 3).

When we collect "communication/compliance problem with the spouse" + "conflict with the mother-in-law/other family members" + "breaking up with the beloved one" + "husband's cheating on her" stressor groups as a "relationship conflict" group, the mean age of the groups were $28 \pm 7.60$ years for "relationship conflict" group; $40 \pm$ 10.80 years for "health problem" group and $22 \pm 6.05$ years for "moving/immigrating" group $(p<0.01)$. Post-hoc pairwise comparisons revealed that age of "health problem of the relatives" group was significantly higher than age of "relationship conflict" group $(p<0.01)$ and migration group $(p<0.01)$. However, mean age of "relationship conflict" group was not significantly different than that of "moving/immigrating" group $(p=0.135)$.

Duration of education were reported as $8.775 \pm 3.44$ years in "relationship conflict" group, $7.5 \pm 2.99$ years in "health problem of the relatives" group and $6 \pm 2.36$ years in "moving/immigrating" group. It was concluded that there is no significant difference in duration of education among groups $(p=0.07)$.

Duration of marriage were $9.5 \pm 5.81$ years in "relationship conflict" group, $22.3 \pm 13.87$ years in "health problem of the relatives" group and $4.5 \pm 2.76$ years in migration group $(p<0.01)$. Duration of marriage of "health problem of the relatives" group was significantly higher than age of "relationship conflict" group $(p<0.01)$ and 
Table 4. Comparison of clinical features and scale scores of the patients according to psychosocial stressors

\begin{tabular}{|l|c|c|c|c|}
\hline & $\begin{array}{c}\text { Relational Conflicts (n:44) } \\
\text { Mean } \pm \text { SD }\end{array}$ & $\begin{array}{c}\text { Health Problems (n:10) } \\
\text { Mean } \pm \text { SD }\end{array}$ & $\begin{array}{c}\text { Migration (n:8) } \\
\text { Mean } \pm \text { SD }\end{array}$ & p \\
\hline CGI & $4.775 \pm 0.81$ & $3.5 \pm 0.55$ & $3.2 \pm 0.50$ & $<0.01$ \\
\hline GAS & $56 \pm 7.15$ & $61 \pm 7.92$ & $45 \pm 5.81$ & $<0.01$ \\
\hline BDI & $34.05 \pm 9.35$ & $26 \pm 7.32$ & $28 \pm 7.75$ & 0.019 \\
\hline BAI & $39.02 \pm 13.81$ & $36.4 \pm 12.60$ & $38.5 \pm 13.58$ & 0.86 \\
\hline Age & $28 \pm 7.60$ & $40 \pm 10.80$ & $22 \pm 6.05$ & $<0.01$ \\
\hline Education & $8.775 \pm 3.44$ & $7.5 \pm 2.99$ & $6 \pm 2.36$ & 0.07 \\
\hline Marriage & $9.5 \pm 5.81$ & $22.3 \pm 13.87$ & $4.5 \pm 2.76$ & $<.01$ \\
\hline
\end{tabular}

One-way analysis of variance (ANOVA) was used to compare means of more than two groups.

Relational Conflicts: Communication/compliance problem with the spouse + Conflict with the mother-in-law/other family members + Breaking up with the beloved one + Husband's cheating on her

"moving/immigrating" group ( $p<0.01)$. Duration of marriage of "relationship conflict" group was not significantly different than that of "moving/immigrating" group $(p=0.193)$.

The mean of the CGI scores were $4.775 \pm 0.81$ in "relationship conflict" group, $3.5 \pm 0.55$ in "health problem of the relatives" group and $3.2 \pm 0.50$ in "moving/immigrating" group. CGI scores were significantly different among groups $(p<0.01)$. Post-hoc pairwise comparisons revealed that $C G I$ scores of "relationship conflict" group was significantly higher than those of "health problem of the relatives" $(p<0.01)$ and "moving/immigrating" groups $(p<0.01)$. However, CGI scores of "health problem" group was not significantly different than that of "moving/immigrating" group $(p=0.673)$.

The mean of the GAS scores were reported as $56 \pm 7.15$ in "relationship conflict" group, $61 \pm 7.92$ in "health problem of the relatives" group and $45 \pm 5.81$ in "moving/immigrating" group. GAS scores were also significantly different among groups ( $p<0.01$ ). GAS scores of "health problem" group was significantly higher than those of "relationship conflict" group ( $p<0.01)$ and "moving/immigration" groups $(p<0.01)$. GAS scores of "relationship conflict" group was not significantly different than that of "moving/immigration" group $(p=0.121)$.

The mean of the BDI scores were reported as $34.05 \pm 9.35$ in "relationship conflict" group, $26 \pm 7.32$ in "health problem of the relatives" group and $28 \pm 7.75$ in "moving/immigration" group. Depression levels were significantly different among groups $(p<0.019)$. Post-hoc pairwise comparisons revealed that depression levels of "relationship conflict" group was significantly higher compared to "health problem of the relatives" group $(p<0.032)$. Depression levels of "moving/immigration" group was not significantly different than those of "relational conflict" group $(p=0.188)$ and "health problem of the relatives" group $(p<0.884)$.
The mean of the BAI scores were $39.02 \pm 13.81$ in "relationship conflict" group, $36.4 \pm 12.60$ in "health problem of the relatives" group and $38.5 \pm 13.58$ in "moving/immigration" group. Anxiety levels were not significantly different among groups $(p=0.86)$.

\section{DISCUSSION}

Before we started the study, we had hypothesized that among the possible potential risk factors the conflicts with close relatives are the most common concurrency with depression. Also, we had hypothesized that married females with children may have much more risk for depression about marriage problems. The present study actually identified that conflict with the spouse and his family (mother-in-law in particular) is the most possible potential psychosocial stress factor triggering the MDD. In addition, many patients stated that the husband's family makes contribution to this conflict with the spouse. In our study it was also found that depression levels of "relationship conflict" group was significantly higher compared to "health problem of the relatives" group $(p<0.032)$. The mean of BDI and BAI scores of "relationship conflict" group were highest among the all groups. In addition, "relationship conflict" group presents more negative results in CGI scores, when we evaluate these together it appears compatible with previous studies that shows the effects of relational problems on depression [6]. The literature as well reveal that, overall health status of the females in conflicting families is unfavorably influenced, whereas the mental health of females is better in the families with close relationship where the emotions are clearly expressed [19]. In a study from Australia comprising 3820 subjects, depression and anxiety symptoms were found to be more common in the females with poor quality of relationship as compared to the females with good quality of relationship and to the single females [20]. Again, studies reported that subjects with high sociotropic values (need and dependency of an individual for having positive relations with other people) are more sensitive to 
interpersonal relations than the autonomous subjects and that, conflicts in these areas would more strongly trigger the depression in sociotropic subjects [21]. The present study population is highly sociotropic (10 out of 48 married females have been living with the husband's family and many others have been residing closer) as compared to the western populations. This may explain why interpersonal conflict with the spouse and close relatives (mother-in-law) is the leading triggering factor for major depressive disorder in the present study while mourning and separation are the leading triggering factors in the western populations.

Of the study population, 48 were married, 12 were single and 2 were divorced. Again, 50 patients had children while 12 had none. Statistics confirm that mental diseases are less common in married subjects, which switch to relatively more routine and stable life, than the single subjects. The subjects do not only obtain sexual satisfaction and comfort in marriage but also gain numerous safety measures. Marriage largely impresses ability of interpersonal compliance and sense of responsibility upon the subject. The lack or deficiency of these necessities predisposes many mental problems particularly in females [22]. The literature comprises also the contradictory studies similar to the present study. These studies report that marriage has more negative impacts on women [5]. In the present study, the study population's consisting largely of married women (77.4\%) exposes the importance of intra-marital conflicts in reactive depression. The probability of women with children, who are accounted for the majority of the study population (80.6\%), not having enough support for child care due to the conflict with the husband can be addressed as the reason for high mean BAI scores and accordingly high BDI scores of the study population.

Again, it is seen that females diagnosed with major depressive disorder are composed largely of middle-aged females graduated from primary school. Depression can be seen at any age, but is more common in the middle ages particularly between 25 and 44 years [5], which is consistent with our findings suggesting that depression is more prevalent at middle ages. Literature review propounds that the risk of depression is higher in the subjects with the following characteristics: low education level and low income, unemployment, loss of the beloved one, financial difficulty, and low social level [23]. Again, a study conducted to determine whether high education level is a protective factor against depression and anxiety found significant relationship between low education level and anxiety and depression [24].
Opinions concerning that chronic stress and acute stress trigger MDD are controversial [3]. The majority of the researchers think that presence of chronic stress increases the risk of MDD triggered by acute stress (sensitivity), whereas limited number of researchers state just the opposite that chronic stress reduces (strengthen) the acute stress's triggering effect on MDD $[25,26]$. Some researchers, however, report that the effects of acute stress and chronic stress are not associated with each other and that they need to be evaluated separately. In the present study, we did not evaluate acute stress and chronic stress separately, but tried to identify the psychosocial factors that the patients considered associated with MDD. We observed that such a distinction is difficult to make and that chronic and acute factors determine each other and are engaged. For example, many patients that experience conflict with husband or mother-in-law for a long time present to the clinic with enhanced symptoms following an acute problem with these subjects. In fact, there is no consistency even between the efforts made to define chronic stress; i.e. "chronic" stands sometimes for the effects lasting for one month [27] but sometimes for the effects lasting for 12 months [25]. Accordingly, an acute stress for an author might be chronic for another. The present study does not allow us to evaluate whether chronic stress empowers or desensitizes the effect of acute stress.

Evaluation of psychosocial stress is significantly influenced by the person's subjective thoughts and explanation. For this reason, a factor identified as psychosocial stress, e.g. loss of a close relative, does not explain subjective processes. This poses methodological limitation and has the risk of overgeneralization. The fact that the same topic of psychosocial life has different mental outcomes on different people should be kept in mind during evaluation and treatment. Since the patients has been diagnosed with major depression for the first time and had no co-morbidity other than major depression according to SCID-I criteria, the sample size's being small. Again consisting only of female gender, absence of a control group, and the facts that chronic stress and acute stress have not been defined or evaluated separately, a measurement tool that would determine the intensity of the effect of psychosocial stress, assess the endogenous and subjective processes other than psychosocial risk factors and expose personality traits has not been used are the significant limitations of the present study.

Although the presence of psychosocial factors that are highly stressor has been determined before MDD both in the present study and in the earlier studies, it should be kept in 
mind that there are many people not having depression despite the stressors they experience, which confirms that depression is associated not only with psychosocial factors but also the complex interaction between personal trait and many biological and genetic factors. Therefore, psychological, social and biological therapies need to be considered together in the treatment.

\section{DECLARATION OF CONFLICT OF INTEREST}

The authors received no financial support for the research and/or authorship of this article. There is no conflict of interest.

\section{REFERENCES}

1. Assari S, Lankarani MM. Association between stressful life events and depression; intersection of race and gender. Journal of Racial and Ethnic Health Disparities 2016; 3(2): 349-56.

2. Beable S, Fulcher M, Lee AC, Hamilton B. SHARPSports mental Health Awareness Research Project: Prevalence and risk factors of depressive symptoms and life stress in elite athletes. Journal of Science and Medicine in Sport 2017; 20(12): 1047-52.

3. Hammen C, Kim EY, Eberhart NK, Brennan PA. Chronic and acute stress and the prediction of major depression in women. Depression and anxiety 2009; 26(8): 718-23.

4. Monroe SM, Harkness KL. Life stress, the "kindling" hypothesis, and the recurrence of depression: considerations from a life stress perspective. Psychological review 2005; 112(2): 417.

5. Ünal S, Küey L, Güleç C, Bekaroğlu M, Evlice YE, Kırlı S. Depresif bozukluklarda risk etkenleri. Klinik Psikiyatri 2002; 5(1): 8-15.

6. Teo $A R$, Choi $H$, Valenstein $M$. Social relationships and depression: ten-year follow-up from a nationally representative study. PloS one 2013; 8(4).

7. Foo SQ, Tam WW, Ho CS, et al. Prevalence of depression among migrants: A systematic review and meta-analysis. International journal of environmental research and public health 2018; 15(9): 1986.

8. Paykel ES. Life events and affective disorders. Acta Psychiatrica Scandinavica 2003; 108: 61-6.
9. Stroud CB, Davila J, Hammen C, Vrshek-Schallhorn S. Severe and nonsevere events in first onsets versus recurrences of depression: Evidence for stress sensitization. Journal of Abnormal Psychology 2011; 120(1): 142.

10. Monroe SM, Slavich GM, Torres LD, Gotlib IH. Major life events and major chronic difficulties are differentially associated with history of major depressive episodes. Journal of abnormal psychology 2007; 116(1): 116.

11. First MB, Spitzer RL, Gibbon M, Williams JB. User's guide for the Structured clinical interview for DSM-IV axis I disorders SCID-I: clinician version. American Psychiatric Pub. 1997.

12. Çorapçıoğlu A, Aydemir Ö, Yıldız M, Esen A, Köroğlu E. DSM-IV Eksen I Bozuklukları (SCID-I) için yapılandırılmış klinik görüşme, klinik versiyon. Ankara: Hekimler yayın birliği 1999.

13. Guy W. Clinical global impression. Assessment manual for Psychopharmacology 1976: 217-22.

14. Beck AT, Ward CH, Mendelson M, Mock J, Erbaugh J. An inventory for measuring depression. Archives of general psychiatry $1961 ; 4(6):$ 561-71.

15. Hisli N. Beck Depresyon Envanterinin gecerliligi uzerine bit calisma (A study on the validity of Beck Depression Inventory). Psikoloji Dergisi 1988; 6: 118-22.

16. Beck AT, Epstein N, Brown G, Steer RA. An inventory for measuring clinical anxiety: psychometric properties. Journal of consulting and clinical psychology 1988; 56(6): 893.

17. Ulusoy M, Sahin NH, Erkmen H. The Beck anxiety inventory: psychometric properties. Journal of cognitive psychotherapy 1998; 12(2): 163-72.

18. Endicott J, Spitzer RL, Fleiss JL, Cohen J. The Global Assessment Scale: A procedure for measuring overall severity of psychiatric disturbance. Archives of general psychiatry 1976; 33(6): 766-71.

19. Kaur S, Kaur G, Rani C. Family environment in relation To mental health and marital adjustment among rural women of Punjab. Voice of Research 2015; 4(3): 3-37.

20. Leach LS, Butterworth P, Olesen SC, Mackinnon A. Relationship quality and levels of depression and anxiety in a large population-based survey. Social psychiatry and psychiatric epidemiology 2013; 48(3): 417-25. 
21. Hammen C. Stress and depression. Annu Rev Clin Psychol 2005; 1:293-319.

22. Pehlivan K. Psikiyatrik kadın hastalarda evlilik ve ebeveyn olma: Bir gözden geçirme. Düşünen Adam 2006; 19(3): 143-54.

23. Ergöl Ş, Kuzu A. The relation between marriage characteristics and depression and anxiety symptoms in married women aged 15-49 years 15-49 yaş evli kadınlarda depresyon ve anksiyete belirtileri ile evlilik özelliklerinin ilişkisi. Journal of Human Sciences 2016; 13(1): 1023-35.
24. Bjelland I, Krokstad S, Mykletun A, Dahl AA, Tell GS, Tambs K. Does a higher educational level protect against anxiety and depression? The HUNT study. Social science \& medicine 2008; 66(6): 1334-45.

25. Koenen KC, Rudenstine S, Susser E, Galea S. A life course approach to mental disorders. Oxford University Press. 2013.

26. Cairney J, Boyle M, Offord DR, Racine Y. Stress, social support and depression in single and married mothers. Social psychiatry and psychiatric epidemiology 2003; 38(8): 442-9.

27. Lin N, Dean A, Ensel WM. Social support, life events, and depression. Academic Press. 2013. 